\title{
Natural Radioactivity and Radiological Impact Assessment of Soil, Food and Water around Iron and Steel Smelting Area in Fashina Village, Ile-Ife, Osun State, Nigeria
}

\section{${ }^{1}$ OLUYIDE, S.O; ${ }^{1}$ TCHOKOSSA, P; ${ }^{* 1,3}$ OROSUN, MM; ${ }^{1}$ AKINYOSE, FC; ${ }^{4}$ LOUIS, H; ${ }^{2}$ IGE, SO}

\author{
${ }^{I}$ Department of Physics, Obafemi Awolowo University, Ile-Ife, Osun State, Nigeria \\ ${ }^{2}$ Department of Physics, University of Ilorin, Ilorin, Kwara State, Nigeria \\ ${ }^{3}$ Institute of Ecology and environmental Studies, Ile-Ife, Osun State, Nigeria \\ ${ }^{4}$ CAS Key Laboratory for Nano-system and Hierarchical Fabrication, National Centre for Nanoscience and Technology, University of \\ Chinese Academy of Sciences, Beijing, China.
}

*Corresponding Author Email: muyiwaorosun@yahoo.com

\begin{abstract}
This study assessed the natural radioactivity and radiological health impact of thirty-eight (38) samples of soil, food and water in Fashina village, Ile-Ife, Osun State, Nigeria using portable survey meter with a Global Positioning System (GPS) and well-calibrated NaI(Tl) detector system The mean exposure rates in the study area were $0.14 \mu \mathrm{Sv} \mathrm{hr}^{-1}$ and $0.12 \mu \mathrm{Sv} \mathrm{hr}^{-1}$ in soil/food and water samples respectively. The mean radioactivity content obtained for ${ }^{238} \mathrm{U},{ }^{232} \mathrm{Th}$ and ${ }^{40} \mathrm{~K}$ were $12.14 \pm 4.17 \mathrm{~Bq} \mathrm{~kg}^{-1}, 23.23 \pm 7.67 \mathrm{~Bq} \mathrm{~kg}{ }^{-1}$ and $270.14 \pm 61.79 \mathrm{~Bq} \mathrm{~kg}^{-1}$ respectively in soil samples and $8.56 \pm 2.80 \mathrm{~Bq} \mathrm{~kg}{ }^{-1}, 13.17 \pm 4.48 \mathrm{~Bq} \mathrm{~kg}^{-1}$ and $89.41 \pm 24.15 \mathrm{~Bq} \mathrm{~L}^{-1}$ respectively for ${ }^{238} \mathrm{U},{ }^{232} \mathrm{Th}$ and ${ }^{40} \mathrm{~K}$ in water samples. The mean values of $30.91,15.64$ and $12.47 \mathrm{nGy} \mathrm{h}^{-1}$ were obtained for the absorbed dose rate in soil, food and water, respectively, while $37.90,178.79$ and $1085.23 \mu \mathrm{Sv} \mathrm{y}^{-1}$ were obtained for the Annual Effective Doses (AED). Similarly, the Radium equivalent $\left(\mathrm{Ra}_{\mathrm{eq}}\right)$ were $66.16 \mathrm{~Bq} \mathrm{~kg}^{-1}, 34.28 \mathrm{~Bq} \mathrm{~kg}^{-1}$ and $27.31 \mathrm{BqL}^{-1}$, in soil, food and water, respectively. The external and internal radiation hazard indices were 0.18 and $0.21,0.09$ and $0.12,0.07$ and 0.09 , respectively for soil, food and water. The values obtained for the Excess Lifetime Cancer Risk (ELCR) in $\left(\mathrm{x} 10^{-3}\right)$ were also $0.13,0.63$ and 3.80 for the soil, food and water samples, respectively. It was found that the values of some exposure rate, radioactivity contents and radiological impact parameters in the study area which were higher than those of the control area and the world average values poses a serious health risk to the environment and its inhabitants.
\end{abstract}

\section{DOI: $\underline{\text { https://dx.doi.org/10.4314/jasem.v23i1.20 }}$}

Copyright: Copyright $(92019$ Oluyide et al. This is an open access article distributed under the Creative Commons Attribution License (CCL), which permits unrestricted use, distribution, and reproduction in any medium, provided the original work is properly cited.

Dates: Received: 18 December 2018; Revised: 21 January 2019; Accepted 24 January 2019

Keywords: Radioactivity, Scrap Metal, Gamma Spectrometry, Radiological Impact Parameter

A radionuclide is an atom with an unstable nucleus, characterized by excess energy available to be imparted either to a newly created radiation particles within the nucleus or via internal conversion. During this process, the radionuclide is said to undergo radioactive decay, resulting in the emission of gamma ray(s) and/or subatomic particles such as alpha or beta particles (Petrucci et al., 2002). Radiation is energetic particle or wave which travels through a vacuum, or through matter-containing medium that are not required for its propagation (Kwan-Hoong, 2003). The absorption of this energy from radiation in biological material may lead to excitation or ionization (Akinyose et al., 2018; Hall, 2000).Radiation is everywhere in our environment and it has been since, from outer space (Cosmic Radiation), the ground (Terrestrial Radiation) and even from within our bodies. The radioactivity level from the natural radionuclides is generally termed as background radiation which depends on the amount of the radioactive materials in the environment. The background radiation can be high if the environment is polluted either from man-made or natural activities. Radiation has effects on humans depending on the dose absorbed. High radiation dose may alter the DNA of human while low dose may have no appreciable effect.Biologic effects of radiation exposure are classified as either stochastic or deterministic (Hall, 2000).A deterministic effect has a threshold of dose, and the severity of the effect is dose-related for example skin reddening while stochastic effects have no dose threshold and it is based on the molecular mechanisms involved, example of this is cancer or a hereditary defect.The iron and steel company along Ife-Ibadan road involves in the recycling of secondary steel metals which release various particles that may be associated with radioactive contaminants. These emissions do 
not only degrade the soil, vegetation and water, but also increase the rate of occurrence of some common diseases in the populace (UNECE, 2006). The specific objective of this study is to assess the natural radioactivity and evaluate the radiation hazard parameters for the samples of soil, food crop and water collected from the areas around the iron and steel smelting area in Fashina Village, Ile-Ife, to ascertain the level to which the people living in and around the company are exposed to radiation hazard.

\section{MATERIALS AND METHODS}

The Study Area: The study area (Fashina) is located in Ife Central Local Government Area of Osun State, Southwest Nigeria on latitude $7^{\circ} 27^{\prime} \mathrm{N}$ and $7^{\circ} 37^{\prime} \mathrm{N}$ and longitude $4^{\circ} 22^{\prime} \mathrm{E}$ and $4^{\circ} 29^{\prime} \mathrm{E}$ where the iron and steel company is located. This company, since January 2011, is specializing in the use of electric arc furnace in the production of iron bar from the scrap collected from various dumping area. The climate of this area is humid tropical characterized by marked wet and dry season typical south-west of Nigeria. The rainy season covers a period of seven to nine months with two high rainfall peaks and a short dry season. The mean annual rainfall recorded from meteorological station in Teaching and Research Farm of Obafemi Awolowo University, Ile-Ife, for this area is about $1196 \mathrm{~mm}$ and may be higher due to orographic effect. The dry season is associated with the tropical continental air mass with a severe harmattan wind that carries a lot of dust towards the end of the dry season and this season covers a period of four to six months. The control area (Opa) was located in the same Local Government on latitude $7^{\circ}$ 32 'N and $7^{\circ} 34^{\prime \prime} \mathrm{N}$ and longitude $4^{\circ} 32^{\prime \prime} \mathrm{E}$ and $4^{\circ} 35^{\prime \prime} \mathrm{E}$ under the same climatic conditions and about $12 \mathrm{~km}$ (7 miles) from the study area.

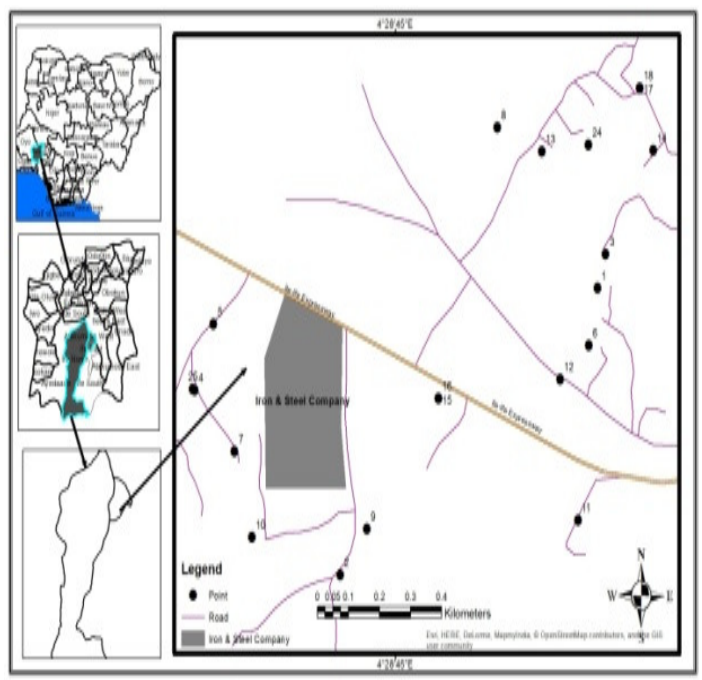

Fig 1: Samples Locations at Fashina Village
Sampling: At the study area, a total number of thirty (30) samples were collected radially around the factory, especially in the cultivated lands while eight (8) samples were collected in Opa area as controls for this case study. The samples comprises of soil, vegetables, fresh cassava, grains and water of different sources such as well, tap, stream and rain water during and after the factory production time. All water samples are treated with acidified with hydrochloric acid $(11 \mathrm{M})$ at the rate of $10 \mathrm{~mL}$ per litre of sample immediately after sampling to avoid adsorption of radionuclides on the walls of the container.Each soil sample and its derived food product were collected by mapping out 1 by $1 \mathrm{~m}^{2}$ at each sampling point. In each sampling square, five core soil samples was taken (four from all the corners and one from the centre) at the depth of $0-30 \mathrm{~cm}$ using a hand towel while its derived food products were also collected within the same sample square point. All the five core soil samples were mixed together to make a composite sample, labelled appropriately after individual placement in polythene bags in order to avoid any mix-up as well as cross contamination. The collected samples were then transport to the laboratory for further processing. The descriptions of the various samples as well as geological survey of the study area are shown in table and figure 1 below. Samples received in the laboratory may not be in the proper physical form for analysis. They may require reduction in size, drying or some form of homogenizing before aliquots can be taken for analysis. The solid samples were oven dried at $85^{\circ} \mathrm{C}$ until a constant weight is attained, then ground and passed through a mesh size of $2 \mathrm{~mm}$ while the larger particles were discarded. All the samples (Soil, Food and Water)which were well labelled then sealed in cylindrical air tight polyvinylchloride containerspreviously and thoroughly washed with dilute $\mathrm{HNO}_{3}$ and rinsed with distilled water and kept for at least 28 days so that the radionuclides in them can attain secular equilibrium after which the activity concentrations were determined on the basis of dry weight in $\mathrm{Bq} \mathrm{kg}^{-}$ ${ }^{1}$.After the secular equilibrium was attained, the gamma spectrometry measurements of the samples were carried out using a well calibrated Sodium Iodide (NaI(TI)) detector at the Centre for Energy Research Development (CERD).

Radiological Impact Parameter: The radiological impact parameters were calculated as follows: Absorbed Dose Rate: The out-door absorbed dose rate " $\mathrm{D}$ " $\left(\mathrm{nGyh}^{-1}\right)$, at a height of $1 \mathrm{~m}$ above the ground surface due to activity concentration of ${ }^{238} \mathrm{U},{ }^{232} \mathrm{Th}$ and ${ }^{40} \mathrm{~K}$ can be calculated using (Orosun et al., 2016) 
$\mathrm{D}_{\mathrm{R}}=\mathrm{c}_{\mathrm{U}} \mathrm{C}_{\mathrm{U}}+\mathrm{c}_{\mathrm{Th}} \mathrm{C}_{\mathrm{Th}}+\mathrm{c}_{\mathrm{K}} \mathrm{C}_{\mathrm{K}}$

where $\mathrm{C}_{\mathrm{U}}, \mathrm{C}_{\mathrm{Th}}, \mathrm{C}_{\mathrm{K}}$ are the radioactivity concentration in $\mathrm{Bq} \mathrm{kg}^{-1}$ and $\mathrm{c}_{\mathrm{U}}, \mathrm{c}_{\mathrm{Th}}$ and $\mathrm{c}_{\mathrm{K}}$ are dose conversion factors for ${ }^{238} \mathrm{U},{ }^{232} \mathrm{Th}$ and ${ }^{40} \mathrm{~K}$, respectively. The values of $\mathrm{c}_{\mathrm{U}}, \mathrm{c}_{\mathrm{Th}}$ and $\mathrm{c}_{\mathrm{K}}$ used in this work are 0.462 , 0.604 and $0.0417 \mathrm{nGyh}^{-1}$.

Annual Effective Dose:a.) The annual effective dose due to ingestion of food products (E) was determined as follows

$\mathrm{E}\left(\mathrm{Sv} \mathrm{y}^{-1}\right)=\mathrm{C}\left(\mathrm{Bq} \mathrm{kg}^{-1}\right) \times \mathrm{M}\left(\mathrm{kg} \mathrm{y}^{-1}\right) \times \mathrm{DCF}\left(\mathrm{Sv} \mathrm{Bq}{ }^{-1}\right)$ (2a)

where $\mathrm{C}$ is the activity concentration of radionuclide, $\mathrm{M}$ is the consumption rate per year and DCF is the standard dose conversion factor which is equal to $0.28 \mu \mathrm{Sv} \mathrm{Bq}^{-1}$ for ${ }^{226} \mathrm{Ra}, 0.23 \mu \mathrm{Sv} \mathrm{Bq}^{-1}$ for ${ }^{232} \mathrm{Th}$ and $0.0062 \mu \mathrm{Sv} \mathrm{Bq}^{-1}$ for ${ }^{40} \mathrm{~K}$ (Amin and Ahmed, 2013), for the person who lived over 17 years (Ali, et al, 2013).

b.) The annual effective dose resulting from the ingestion of water was estimated based on the assumption that a daily intake of water per person is $2 \mathrm{ld}^{-1}$ (WHO, 2011) from the following expression (Orosunet al., 2018; Avwiri, et al.,2013).

$\operatorname{AEDE}\left(\mathrm{mSv} \mathrm{y}^{-1}\right)=\mathrm{I} \times \mathrm{A} \times \mathrm{C} \times 365(2 \mathrm{~b})$

Where AEDE is the annual effective dose, I is the water intake per day $\left(\mathrm{ld}^{-1}\right), \mathrm{A}$ is the daily intake of radionuclide $\left(\mathrm{Bq} \mathrm{L} \mathrm{L}^{-1}\right)$ and $\mathrm{C}$ is the ingestion coefficient of the specific radionuclide $\left(\mathrm{Bq} \mathrm{L}^{-1}\right)$. The standard dose ingestion coefficient is equal to 0.28 $\mu \mathrm{Sv} \mathrm{Bq}^{-1}$ for ${ }^{226} \mathrm{Ra}, 0.23 \mu \mathrm{Sv} \mathrm{Bq}^{-1}$ for ${ }^{232} \mathrm{Th}$ and $0.0062 \mu \mathrm{Sv} \mathrm{Bq}^{-1}$ for ${ }^{40} \mathrm{~K}$ (ICRP, 1994).

c.) The annual effective dose equivalent due to soil received outdoor by a member of the public was calculated from the absorbed dose rate by applying dose conversion factor of $0.7 \mathrm{SvGy}^{-1}$ and occupancy factor for outdoor and indoor of 0.2 and 0.8 respectively (Veiga et al., 2006). AEDE is determined using the following equations (Veiga, et al., 2006).

$\left.\operatorname{AEDE}_{\text {(Outdoor }}\right)\left(\mu \mathrm{Sv} \mathrm{y}^{-1}\right)=$ Absorbed dose $\mathrm{D}(\mathrm{nGy} / \mathrm{h})$ $\times 8760 \mathrm{~h} \times 0.7 \mathrm{~Sv} / \mathrm{Gy} \times 0.2 \times 10^{-3} \quad(2 \mathrm{c})$

The AEDE indoor occurs within a house whereby the radiation risks due to building materials are taken into consideration. AEDE outdoor involves a consideration of the absorbed dose emitted from radionuclide in the environment such as ${ }^{226} \mathrm{Ra},{ }^{232} \mathrm{Th}$ and ${ }^{40} \mathrm{~K}$.
Table 1: Consumption Rate for Different Food Products (Source: Food Balance Sheet, Nigeria, 2014).

\begin{tabular}{ll}
\hline Food Types & Consumption Rate $\left(\mathbf{k g ~ y}^{\mathbf{- 1}}\right)$ \\
\hline Cassava & 124.20 \\
Maize & 31.10 \\
Vegetables & 46.70 \\
Fruits & 59.50 \\
Yams & 100.40 \\
Roots & 8.00 \\
\hline
\end{tabular}

Radium Equivalent Activity Index ( $\left.R a_{e q}\right)$ : Radium equivalent activity index $\left(\mathrm{Ra}_{\mathrm{eq}}\right)$ allows a single index or number to describe the gamma output from different mixtures of ${ }^{238} \mathrm{U},{ }^{232} \mathrm{Th}$ and ${ }^{40} \mathrm{~K}$ in a material. It was calculated using the formula;

$\mathrm{Ra}_{\text {eq }}=\mathrm{C}_{\mathrm{u}}+1.43 \mathrm{C}_{\mathrm{Th}}+0.077 \mathrm{C}_{\mathrm{K}}$

Where $\mathrm{C}_{\mathrm{u}}, \mathrm{C}_{\mathrm{Th}}, \mathrm{C}_{\mathrm{K}}$ are the activity concentration in $\mathrm{Bq}$ $\mathrm{kg}^{-1}$ of ${ }^{238} \mathrm{U},{ }^{232} \mathrm{Th}$ and ${ }^{40} \mathrm{~K}$.

Excess Lifetime Cancer Risk (ELCR): ELCR was calculated using the following equation;

$\mathrm{ELCR}=\mathrm{AEDE} \times \mathrm{DL} \times \mathrm{RF}$

where AEDE, DL and RF are the annual effective dose equivalent, duration of life (70 years) and risk factor $\left(\mathrm{Sv}^{-1}\right)$ (UNSCEAR, 2000).

Radiation Hazard Indices: These indices are used to estimate the level of gamma radiation hazard associated with the natural radionuclide in samples. The external radiation hazard $\left(\mathrm{H}_{\mathrm{ext}}\right)$ and the internal radiation hazard $\left(\mathrm{H}_{\mathrm{int}}\right)$ was calculated as follows:

$\mathrm{H}_{\mathrm{ext}}=\left(\mathrm{C}_{\mathrm{U}} / 370\right)+\left(\mathrm{C}_{\mathrm{Th}} / 259\right)+\left(\mathrm{C}_{\mathrm{K}} / 4810\right)$
$\mathrm{H}_{\mathrm{int}}=\left(\mathrm{C}_{\mathrm{U}} / 185\right)+\left(\mathrm{C}_{\mathrm{Th}} / 259\right)+\left(\mathrm{C}_{\mathrm{K}} / 4810\right)$

Where, $\mathrm{C}_{\mathrm{U}}, \mathrm{C}_{\mathrm{Th}}$ and $\mathrm{C}_{\mathrm{K}}$ are the radioactivity concentration in $\mathrm{Bqkg}^{-1}$ or $\mathrm{Bq} \mathrm{L} \mathrm{L}^{-1}$ of ${ }^{226} \mathrm{Ra},{ }^{232} \mathrm{Th}$, and ${ }^{40} \mathrm{~K}$ respectively. $\mathrm{H}_{\text {in }}$ should be less than unity for the radiation hazard to be negligible. Internal exposure to radon is very hazardous which can lead to respiratory diseases like asthma (Orosunet al., 2018; Tufail, et al., 2007).

\section{RESULTS AND DISCUSSION}

Activity Concentrations of Natural Radionuclides in the Samples: The activity concentrations of the radionuclides in the soil, food and water samples collected from the study area and control locations are presented in Tables 2, 3 and 4 respectively. These results have been used to compute the transfer factor in an earlier work (Oluyide et al., 2018). So in this work, we shall be using them to estimate all the radiological impact parameters to further investigate 
the extent to which people living in the surrounding area of the factory are exposed.

Table 2: Activity Concentration of Radionuclides in Soil Samples

Radiological Impact Parameter in Soil: Absorbed Dose Rate $(\dot{D})$ :The absorbed dose rate $\dot{D}\left(\mathrm{nGy} \mathrm{h} \mathrm{h}^{-1}\right)$ from soil samples collected from the study area and the control locations at $1 \mathrm{~m}$ above the ground level were calculated using equation (1); the results are presented in Table 5.The absorbed dose rate ranged between 17.79 to $46.36 \mathrm{nGy} \mathrm{h}^{-1}$ with an average of $30.91 \mathrm{nGy} \mathrm{h}^{-1}$ for the study area and ranged between 23.11 to $26.66 \mathrm{nGy} \mathrm{h}^{-1}$ with an average of $24.88 \mathrm{nGy}$ $\mathrm{h}^{-1}$ for the control area. The estimated average value in the study was found to be higher than that of the control area but lower when compared to the world average value of $57 \mathrm{nGy} \mathrm{h}{ }^{-1}$ (UNSCEAR, 2000) and hence do not pose any serious health risk.

\begin{tabular}{|c|c|c|c|c|}
\hline \multirow{3}{*}{$\mathrm{S} / \mathrm{N}$} & \multirow{3}{*}{$\begin{array}{l}\text { Samples } \\
\text { Name }\end{array}$} & \multicolumn{2}{|c|}{ Radioactivity Content $\left(\mathrm{Bq} \mathrm{kg}^{-1}\right)$} & \multirow{3}{*}{${ }^{238} \mathbf{U}$} \\
\hline & & ${ }^{40} \mathrm{~K}$ & ${ }^{232} \mathrm{Th}$ & \\
\hline & & \multicolumn{2}{|l|}{ Study Area } & \\
\hline 1 & Soo1 & $92.85 \pm 29.06$ & $32.01 \pm 11.07$ & $20.18 \pm 6.74$ \\
\hline 2 & Soo 2 & $352.62 \pm 88.34$ & $41.22 \pm 12.6$ & $14.62 \pm 5.10$ \\
\hline 3 & Soo3 & $186.62 \pm 40.93$ & $19.73 \pm 6.47$ & $10.22 \pm 3.70$ \\
\hline 4 & Soo4 & $201.60 \pm 51.11$ & $6.28 \pm 2.15$ & $12.10 \pm 4.36$ \\
\hline 5 & Soo5 & $429.07 \pm 84.63$ & $20.33 \pm 5.84$ & $7.28 \pm 2.10$ \\
\hline 6 & Soo6 & $142.62 \pm 30.98$ & $21.76 \pm 5.46$ & $9.07 \pm 2.53$ \\
\hline 7 & Soo 7 & $537.28 \pm 99.28$ & $33.26 \pm 9.53$ & $8.10 \pm 1.84$ \\
\hline 8 & Soo8 & $253.63 \pm 46.47$ & $16.56 \pm 4.89$ & $13.52 \pm 3.54$ \\
\hline 9 & Soo9 & $342.84 \pm 61.73$ & $20.02 \pm 5.63$ & $17.11 \pm 6.03$ \\
\hline \multirow[t]{2}{*}{10} & Soo10 & $162.30 \pm 35.92$ & $21.15 \pm 7.06$ & $9.19 \pm 2.55$ \\
\hline & MEAN & $\begin{array}{l}270.14 \pm 61.79 \\
\text { Control Area }\end{array}$ & $23.23 \pm 7.67$ & $12.14 \pm 4.17$ \\
\hline 11 & Soo11 & $202.53 \pm 32.22$ & $18.16 \pm 4.58$ & $11.82 \pm 3.11$ \\
\hline 12 & Soo12 & $264.65 \pm 51.02$ & $19.67 \pm 6.81$ & $8.11 \pm 2.51$ \\
\hline \multirow[t]{2}{*}{13} & Soo13 & $193.86 \pm 41.78$ & $20.31 \pm 4.11$ & $5.98 \pm 1.47$ \\
\hline & MEAN & $220.35 \pm 42.37$ & $19.38 \pm 5.30$ & $8.64 \pm 2.46$ \\
\hline
\end{tabular}

Table 3: Activity Concentration of Radionuclides in Food Samples

\begin{tabular}{|c|c|c|c|c|c|c|}
\hline \multirow{3}{*}{$\mathrm{S} / \mathrm{N}$} & \multirow{2}{*}{\multicolumn{3}{|c|}{ Sample Names }} & \multicolumn{3}{|c|}{ Radioactivity Content $\left(\mathrm{Bq} \mathrm{kg}^{-1}\right)$} \\
\hline & & & & \multirow{2}{*}{$\begin{array}{l}{ }^{40} \mathrm{~K} \\
\text { Study Area }\end{array}$} & \multirow[t]{2}{*}{${ }^{232} \mathrm{Th}$} & \multirow[t]{2}{*}{${ }^{238} \mathbf{U}$} \\
\hline & $\begin{array}{l}\text { Sample } \\
\text { Code }\end{array}$ & English Names & Botanical Names & & & \\
\hline 1 & VSo1 & Water Leaves@ @ashina 1 & Talinumtriangulae & $60.12 \pm 21.72$ & $9.82 \pm 3.15$ & $9.77 \pm 2.83$ \\
\hline 2 & VSo2 & Water Leaves@ Fashina 2 & Talinumtriangulae & $121.53 \pm 30.66$ & $16.72 \pm 4.63$ & $6.75 \pm 2.66$ \\
\hline 3 & VSo3 & Cassava@Fashina 1 & Manihotesculentun & $78.39 \pm 26.73$ & $17.53 \pm 5.62$ & $7.22 \pm 1.98$ \\
\hline 4 & VSo4 & Cassava@Fashina 2 & Manihotesculentun & $98.66 \pm 17.23$ & $13.17 \pm 3.84$ & $8.00 \pm 2.17$ \\
\hline 5 & VSo5 & $\begin{array}{l}\text { Cassava Processed garri @ } \\
\text { Fashina }\end{array}$ & Manihotesculentun & $88.45 \pm 12.98$ & $5.12 \pm 1.15$ & $10.45 \pm 3.77$ \\
\hline 6 & VSo6 & $\begin{array}{l}\text { Jute Leaves @ Fashina } 1 \\
\text { (Ewedu) }\end{array}$ & Corchorus & $53.27 \pm 11.96$ & $8.16 \pm 2.07$ & $13.13 \pm 4.74$ \\
\hline 7 & VSo7 & $\begin{array}{l}\text { Jute Leaves @ Fashina } 2 \\
\text { (Ewedu) }\end{array}$ & Corchorus & $124.9 \pm 29.13$ & $21.15 \pm 7.11$ & $11.44 \pm 2.88$ \\
\hline 8 & VSo8 & $\begin{array}{l}\text { African Spinach @ } \\
\text { Fashina } 1 \text { (Efotete) }\end{array}$ & Amaranthushybridus & $69.93 \pm 20.18$ & $14.76 \pm 5.24$ & $5.74 \pm 1.03$ \\
\hline 9 & VSo9 & $\begin{array}{l}\text { African Spinach @ } \\
\text { Fashina } 2 \text { (Efotete) }\end{array}$ & Amaranthushybridus & $111.55 \pm 39.31$ & $16.28 \pm 6.01$ & $7.86 \pm 2.41$ \\
\hline \multirow[t]{3}{*}{10} & VSo10 & $\begin{array}{l}\text { Dried Yellow Maize @ } \\
\text { Fashina }\end{array}$ & Zea mays & $87.25 \pm 17.25$ & $8.99 \pm 1.88$ & $5.27 \pm 1.70$ \\
\hline & MEAN & & & $89.41 \pm 24.15$ & $13.17 \pm 4.48$ & $8.56 \pm 2.80$ \\
\hline & & & & Control Area & & \\
\hline 11 & VSo11 & Water Leaves@Opa & Talinumtriangulae & $46.58 \pm 9.38$ & $9.37 \pm 3.26$ & $10.27 \pm 4.26$ \\
\hline 12 & VSo12 & Dried White Maize @opa & Zea mays & $52.17 \pm 18.17$ & $6.02 \pm 2.11$ & $9.42 \pm 4.18$ \\
\hline \multirow[t]{2}{*}{13} & VSo13 & Jute Leaves @Opa & Corchorus & $64.34 \pm 20.43$ & $3.35 \pm 2.02$ & 0 \\
\hline & MEAN & & & $54.36 \pm 16.69$ & $6.56 \pm 2.53$ & $8.01 \pm 2.45$ \\
\hline
\end{tabular}

Annual Effective Dose: The annual effective dose equivalent from soil samples received outdoor by members of the public were calculated using equation (2c); the results are presented in Table 5. It ranged from 21.82to $56.85 \mu \mathrm{Svy}^{-1}$ with an average of $37.90 \mu \mathrm{Svy}^{-1}$ for the study area and between 28.35 to $32.70 \mu \mathrm{Sv} \mathrm{y}^{-1}$ with an average of $30.52 \mu \mathrm{Sv} \mathrm{y}^{-1}$ for control area. The estimated average value in the study area was higher than the control environment but lower than the world average value of $290 \mu \mathrm{Sv} \mathrm{y} \mathrm{y}^{-1}$ by UNSCEAR (2000) and hence poses no serious health risk.
Radium Equivalent activity Index $\left(R a_{\text {eq }}\right)$ :The Radium Equivalent Activity Index $\left(\mathrm{Ra}_{\mathrm{eq}}\right)$ from soil samples analyzed were calculated using equation (3); is presented in Table 5.The results ranged between 36.60 to $100.72 \mathrm{~Bq} \mathrm{~kg}^{-1}$ with an average of $66.16 \mathrm{~Bq}$ $\mathrm{kg}^{-1}$ for the study area and 49.95 to $56.62 \mathrm{~Bq} \mathrm{~kg}^{-1}$ with an average of $53.32 \mathrm{~Bq} \mathrm{~kg}^{-1}$ for the control area. In the study area, the obtained average value was high in comparison with the control environment but below the world average value of $370 \mathrm{~Bq} \mathrm{~kg}^{-1}$ and hence poses no serious health risk (UNSCEAR, 2000). 
Table 4: Activity Concentration of Radionuclides in Water Samples

\begin{tabular}{|c|c|c|c|c|}
\hline \multirow{3}{*}{$\mathbf{S} / \mathbf{N}$} & \multirow{3}{*}{$\begin{array}{l}\text { Sample } \\
\text { Names }\end{array}$} & \multicolumn{3}{|c|}{ Radioactivity Content $\left(\mathrm{Bq} \mathrm{L}^{-1}\right)$} \\
\hline & & ${ }^{40} \mathrm{~K}$ & ${ }^{232} \mathrm{Th}$ & ${ }^{238} \mathbf{U}$ \\
\hline & & \multicolumn{3}{|l|}{ Study Area } \\
\hline 1 & WSO1 & $65.38 \pm 15.67$ & $4.41 \pm 1.34$ & $4.15 \pm 2.11$ \\
\hline \multirow[t]{2}{*}{2} & WSO2 & $98.62 \pm 20.92$ & $8.12 \pm 2.23$ & $6.21 \pm 2.34$ \\
\hline & MEAN & $\mathbf{8 2 . 0 0} \pm 18.30$ & $6.27 \pm 1.79$ & $\mathbf{5 . 1 8} \pm 2.23$ \\
\hline 3 & WSO3 & $46.09 \pm 11.28$ & $10.11 \pm 3.16$ & $8.14 \pm 2.21$ \\
\hline \multirow[t]{2}{*}{4} & WSO4 & $62.91 \pm 19.62$ & $9.73 \pm 4.02$ & $7.12 \pm 3.11$ \\
\hline & MEAN & $\mathbf{5 4 . 5 0} \pm 15.45$ & $\mathbf{9 . 9 2} \pm 3.59$ & $7.63 \pm 2.66$ \\
\hline 5 & WSO5 & $96.58 \pm 20.01$ & $13.02 \pm 2.92$ & $11.02 \pm 4.21$ \\
\hline \multirow[t]{2}{*}{6} & WSO6 & $53.82 \pm 13.27$ & $7.78 \pm 3.17$ & $5.38 \pm 2.27$ \\
\hline & MEAN & $\mathbf{7 5 . 2 0} \pm 16.64$ & $\mathbf{1 0 . 4} \pm 3.05$ & $8.20 \pm 3.24$ \\
\hline 7 & WSO7 & $77.38 \pm 9.15$ & $13.04 \pm 6.02$ & $8.06 \pm 3.12$ \\
\hline \multirow[t]{2}{*}{8} & WSO8 & $47.08 \pm 12.58$ & $8.16 \pm 3.01$ & $5.28 \pm 2.10$ \\
\hline & MEAN & $\mathbf{6 2 . 2 3} \pm 11.05$ & $\mathbf{1 0 . 6 0} \pm 4.52$ & $6.67 \pm 2.61$ \\
\hline 9 & WSO9 & $55.67 \pm 14.34$ & $16.05 \pm 2.19$ & $12.01 \pm 3.41$ \\
\hline \multirow[t]{4}{*}{10} & WSO10 & $86.89 \pm 11.28$ & $9.99 \pm 5.01$ & $9.03 \pm 4.10$ \\
\hline & MEAN & $71.28 \pm 12.81$ & $13.02 \pm 3.60$ & $10.52 \pm 3.76$ \\
\hline & $\begin{array}{l}\text { OVERALL } \\
\text { MEAN }\end{array}$ & $69.04 \pm 15.29$ & $10.04 \pm 3.31$ & $7.64 \pm 2.90$ \\
\hline & Control Area & & & \\
\hline 11 & WSO11 & $69.83 \pm 20.14$ & $11.74 \pm 4.18$ & $11.53 \pm 3.87$ \\
\hline \multirow[t]{2}{*}{12} & WSO12 & $61.96 \pm 16.20$ & $9.89 \pm 2.26$ & $7.36 \pm 3.08$ \\
\hline & MEAN & $65.90 \pm 18.17$ & $10.82 \pm 3.22$ & $9.45 \pm 3.48$ \\
\hline
\end{tabular}

Table 5: Radiological Impact Parameters in Soil Samples

\begin{tabular}{|c|c|c|c|c|c|c|c|}
\hline $\mathbf{S} / \mathbf{N}$ & $\begin{array}{l}\text { Samples } \\
\text { Name }\end{array}$ & $\begin{array}{c}\dot{D} \\
\left(\mathbf{n G y h}^{-1}\right)\end{array}$ & $\begin{array}{l}\text { AEDE } \\
\left(\mu \mathbf{S v y}^{-1}\right)\end{array}$ & $\begin{array}{l}\mathbf{R a}_{\mathrm{eq}} \\
\left(\mathbf{B q ~ k g} \mathbf{k g}^{-1}\right)\end{array}$ & $\begin{array}{l}\text { ELCR } \\
\left(\mathbf{x 1 0}^{-3}\right)\end{array}$ & $\mathbf{H}_{\mathrm{ex}}$ & $\mathbf{H}_{\text {in }}$ \\
\hline & \multicolumn{7}{|c|}{ Study Area } \\
\hline 1 & Soo1 & 32.53 & 39.89 & 73.10 & 0.14 & 0.20 & 0.25 \\
\hline 2 & Soo2 & 46.36 & 56.85 & 100.72 & 0.20 & 0.27 & 0.31 \\
\hline 3 & Soo3 & 24.42 & 29.95 & 52.80 & 0.10 & 0.14 & 0.17 \\
\hline 4 & Soo4 & 17.79 & 21.82 & 36.60 & 0.08 & 0.10 & 0.13 \\
\hline 5 & Soo5 & 33.53 & 41.13 & 69.39 & 0.14 & 0.19 & 0.21 \\
\hline 6 & Soo6 & 23.28 & 28.55 & 51.17 & 0.10 & 0.14 & 0.16 \\
\hline 7 & Soo7 & 46.24 & 56.70 & 97.03 & 0.20 & 0.26 & 0.28 \\
\hline 8 & Soo8 & 26.82 & 32.90 & 56.73 & 0.12 & 0.15 & 0.19 \\
\hline 9 & Soo9 & 34.29 & 42.06 & 72.14 & 0.15 & 0.19 & 0.24 \\
\hline \multirow[t]{3}{*}{10} & Soo10 & 23.79 & 29.17 & 51.93 & 0.10 & 0.14 & 0.17 \\
\hline & MEAN & 30.91 & 37.90 & 66.16 & 0.13 & 0.18 & 0.21 \\
\hline & \multicolumn{7}{|c|}{ Control Area } \\
\hline 11 & Soo11 & 24.87 & 30.51 & 53.38 & 0.11 & 0.14 & 0.18 \\
\hline 12 & Soo12 & 26.66 & 32.70 & 56.62 & 0.11 & 0.15 & 0.17 \\
\hline \multirow[t]{2}{*}{13} & Soo13 & 23.11 & 28.35 & 49.95 & 0.10 & 0.13 & 0.15 \\
\hline & MEAN & 24.88 & 30.52 & 53.32 & 0.11 & 0.14 & 0.17 \\
\hline
\end{tabular}

Excess Lifetime Cancer Risk (ELCR):The excess lifetime cancer risk for the analyzed soil samples were calculated using equation (4); the results are shown in Table 5. The excess lifetime cancer risk ELCR ranged between $0.10 \times 10^{-3}$ to $0.20 \times 10^{-3}$ with an average of $0.13 \times 10^{-3}$ for the study area and between $0.10 \times 10^{-3}$ to $0.11 \times 10^{-3}$ with an average of $0.11 \times 10^{-3}$ for control area. It is important to note that the average value obtained in the study area was lower than the world average value of $0.2 \times 10^{-3}$ (UNSCEAR, 2000). However, this value was higher than that in the control environment. Staying in this environment with an average of 70 years without interacting with other areas in terms of feeding and shelter may pose no serious cancer risk.
Radiation Hazard Indices: The radiation hazard indices in analyzed soil samples, both the external and the internal were calculated using equation (5a) and $(5 \mathrm{~b})$ respectively. The results are shown in Table5. The external radiation hazard index $\left(\mathrm{H}_{\mathrm{ext}}\right)$ ranged from 0.10 to 0.27 with an average of 0.18 for the study area and0.13 to 0.15 with an average of 0.14 for the control area. The internal radiation hazard index $\left(\mathrm{H}_{\mathrm{int}}\right)$ ranged 0.13 to 0.25 with an average of 0.21 for the study area and 0.15 to 0.18 with an average of 0.17 for the control. The values gotten for the two indices were found to be lower than the world average value of 1 (unity) and therefore pose no serious health risk (Beretka and Mathew, 1985).It was noted that the internally deposited radionuclides in all the analyzed samples were greater than external exposure due to the levels 
of radon which is very hazardous airborne radionuclide that can lead to respiratory diseases like asthma (EPA, 2015; Tufail, et al, 2007). And according to the statement of one of the residence in the study area, most of the populace does stay indoor when this factory is producing; this poses serious health risk to the populace.

Radiological Impact Parameter in Food: Absorbed Dose Rate $(\dot{D})$ :The absorbed dose rate $\dot{D}\left(\mathrm{nGy} \mathrm{h}^{-1}\right)$ in analyzed food samples at $1 \mathrm{~m}$ above the ground level were calculated using equation (1); the results are presented in Table 6. It values ranged between 11.50 to $23.27 \mathrm{nGy} \mathrm{h}^{-1}$ with an average of $15.64 \mathrm{nGy} \mathrm{h} \mathrm{h}^{-1}$ for the study area and ranged between 4.71 to $12.35 \mathrm{nGy}$ $\mathrm{h}^{-1}$ with an average of $9.07 \mathrm{nGy}^{-1}$ for the control area. In the study area, the obtained average value was high in comparison with the control environment and below the world average value of $57 \mathrm{nGy} \mathrm{h}^{-1}$ by UNSCEAR (2000) and hence poses no serious health risk.

Annual Effective Dose ( $\left.\mu S v y r^{-1}\right)$ : The results of the annual effective dose due to ingestion of food were estimated using equation (2a). The values are presented in Table 6. It ranged from 99.69 to $276.97 \mu \mathrm{Sv} \mathrm{y}^{-1}$ with an average of $178.79 \mu \mathrm{Sv} \mathrm{y}^{-1}$ for the study area and between 53.05 to $130.86 \mu \mathrm{Sv} \mathrm{y}^{-1}$ with an average of $93.40 \mu \mathrm{Sv} \mathrm{y}^{-1}$ in the control area. The world average value of $290 \mu \mathrm{Sv} \mathrm{y}{ }^{-1}$ (UNSCEAR, 2000) was higher than the obtained mean values for both study and control environments and hence poses no serious health to residence of this area.

Radium Equivalent activity Index $(R a \quad$ eq $)$ : The Radium Equivalent Activity Index $\left(\mathrm{Ra}_{\mathrm{eq}}\right)$ in analyzed food samples were calculated using equation (3). The values are presented and illustrated in Table 6 . The results ranged between 24.58 to $51.30 \mathrm{~Bq} \mathrm{~kg}^{-1}$ with an average of $34.28 \mathrm{~Bq} \mathrm{~kg} \mathrm{~kg}^{-1}$ for the study area and between 9.74 to $27.26 \mathrm{~Bq} \mathrm{~kg}{ }^{-1}$ with an average of $19.68 \mathrm{~Bq} \mathrm{~kg}^{-1}$ for the control area. In the study area, the obtained average value was high in comparison with the control environment and below the world average valueof $370 \mathrm{~Bq} \mathrm{~kg}^{-1}$ and hence poses no serious health risk (UNSCEAR 2000).

Excess Lifetime Cancer Risk (ELCR): The excess life time cancer risk for the analyzed food samples were calculated using equation (4); the results are shown in Table6. The value ranged between $0.35 \times 10^{-3}$ to 0.97 $\mathrm{x} 10^{-3}$ with an average of $0.63 \times 10^{-3}$ for the study area and between $0.19 \times 10^{-3}$ to $0.46 \times 10^{-3}$ with an average of $0.33 \times 10^{-3}$ for the control area. It is important to note that the obtained average values were higher than the world average value of $0.2 \times 10^{-}$ 3 (UNSCEAR, 2000) for both the study and control area environments. This implies that staying in this environment with an average of 70 years without interacting with other areas in terms of feeding and shelter may pose serious cancer risk.

Radiation Hazard Indices: The radiation hazard indices from the analyzed food samples, both the external and the internal were calculated using equation (5a) and (5b) respectively. The results are shown in Table 6 . The external radiation hazard index $\left(\mathrm{H}_{\text {ext }}\right)$ ranged between 0.07 to 0.11 with an average of 0.09 for the study area and 0.03 to 0.07 with an average of 0.05 for the control area, while the internal radiation hazard index $\left(\mathrm{H}_{\mathrm{int}}\right)$ ranged between 0.08 to 0.16 with an average of 0.12 for the study area and between 0.03 to 0.10 with an average of 0.07 for the control area. These values were lower than the world average value of 1 (unity) and hence pose no serious health risk (Beretka and Mathew, 1985).

Table 6: Radiological Impact Parameters in Food Samples

\begin{tabular}{|c|c|c|c|c|c|c|c|}
\hline $\mathbf{S} / \mathbf{N}$ & $\begin{array}{l}\text { Samples } \\
\text { Name }\end{array}$ & $\begin{array}{c}\dot{D} \\
\left(\mathrm{nGyh}^{-1}\right)\end{array}$ & $\begin{array}{l}\text { AEDE } \\
\left(\mu \boldsymbol{S v y}^{-1}\right)\end{array}$ & $\begin{array}{l}\mathbf{R a}_{\mathrm{eq}} \\
\left(\mathrm{Bq} \mathrm{kg}^{-1}\right)\end{array}$ & $\begin{array}{l}\text { ELCR } \\
\left(\mathbf{x 1 0}^{-3}\right)\end{array}$ & $\mathbf{H}_{\mathrm{ex}}$ & $\mathbf{H}_{\text {in }}$ \\
\hline & \multicolumn{7}{|c|}{ Study Area } \\
\hline 1 & VSo1 & 12.95 & 138.37 & 28.44 & 0.48 & 0.08 & 0.10 \\
\hline 2 & VSo2 & 18.29 & 220.84 & 40.02 & 0.77 & 0.11 & 0.13 \\
\hline 3 & VSo3 & 17.19 & 217.64 & 38.32 & 0.76 & 0.10 & 0.12 \\
\hline 4 & VSo4 & 15.76 & 180.31 & 34.43 & 0.63 & 0.09 & 0.12 \\
\hline 5 & VSo5 & 11.61 & 99.69 & 24.58 & 0.35 & 0.07 & 0.10 \\
\hline 6 & VSo6 & 13.22 & 126.24 & 28.90 & 0.44 & 0.08 & 0.11 \\
\hline 7 & VSo7 & 23.27 & 276.97 & 51.30 & 0.97 & 0.14 & 0.16 \\
\hline 8 & VSo8 & 14.48 & 183.69 & 32.23 & 0.64 & 0.09 & 0.10 \\
\hline 9 & VSo9 & 18.12 & 215.71 & 39.73 & 0.75 & 0.11 & 0.13 \\
\hline \multirow[t]{3}{*}{10} & VSo10 & 11.50 & 128.45 & 24.84 & 0.45 & 0.07 & 0.08 \\
\hline & MEAN & 15.64 & 178.79 & 34.28 & 0.62 & 0.09 & 0.12 \\
\hline & \multicolumn{7}{|c|}{ Control Area } \\
\hline 11 & VSo11 & 12.35 & 130.86 & 27.26 & 0.46 & 0.07 & 0.10 \\
\hline 12 & VSo12 & 10.16 & 96.31 & 22.05 & 0.34 & 0.06 & 0.09 \\
\hline \multirow[t]{2}{*}{13} & VSo13 & 4.71 & 53.05 & 9.74 & 0.19 & 0.03 & 0.03 \\
\hline & MEAN & 9.07 & 93.40 & 19.68 & 0.33 & 0.05 & 0.07 \\
\hline
\end{tabular}


Radiological Impact Parameter in Water: Absorbed Dose Rate $(\dot{D})$ :The absorbed dose rate $\dot{D}\left(\mathrm{nGy} \mathrm{h}^{-1}\right)$ in analyzed water samples were calculated using equation (1), with the results as presented in Table7. The mean absorbed dose rate values ranged between 9.60 to $15.70 \mathrm{nGy} \mathrm{h}^{-1}$ with an average of $12.47 \mathrm{nGy} \mathrm{h}^{-1}$ for the study area and between 11.96 to $15.33 \mathrm{nGy} \mathrm{h}^{-1}$ with an average of $13.64 \mathrm{nGy} \mathrm{h}^{-1}$ for the control area. In this study, the estimated average values was higher than the control environment but lower than the world average value of $57 \mathrm{nGy} \mathrm{h} \mathrm{h}^{-1}$ (UNSCEAR, 2000) and hence, do not pose serious health.

Annual Effective Dose $\left(\mu S v y r^{-1}\right)$ : The results of the annual effective dose resulting from the ingestion of water samples were estimated using equation (2b) and presented in Table 7 The mean values ranged from 0.77 to $1.38 \mathrm{mSv} \mathrm{y}^{-1}$ with an average of $1.09 \mathrm{mSv}$ $\mathrm{y}^{-1}$ for the study areaand ranged between 1.05 to
$1.29 \mathrm{mSv}^{-1}$ with an average of $1.17 \mathrm{mSv} \mathrm{yr}^{-}$ ${ }^{1}$ forcontrolarea. From the same table, it can be seen that the AED values ranged from 0.57 (study area) to $1.05 \mathrm{mSv} \mathrm{y}^{-1}$ (control area) in borehole water, and in well water it ranged from 0.83 to $1.44 \mathrm{mSv} \mathrm{y}^{-1}$ (both in the study area). Similarly, it ranged between 1.04 and $1.05 \mathrm{mSv} \mathrm{y}^{-1}$ in stream water (both in study area). The mean AED values for rain water were 1.38 and $1.10 \mathrm{mSv} \mathrm{y}^{-1}$ when the factory was producing and when not producing respectively. It can be seen from the result that the AED values for control was generally higher when compared to the study area, this could be due to the local geophysical properties of the control area. Generally, it was noted that the values estimated for all the water samples in the study and control area were slightly above the world average value of $1 \mathrm{mSv} \mathrm{y}^{-1}$ except for borehole because it has the lowest activity concentration $\left({ }^{238} \mathrm{U}\right.$ and ${ }^{232} \mathrm{Th}$ ) in the study area (ICRP, 1994).

\begin{tabular}{|c|c|c|c|c|c|c|c|c|}
\hline $\mathrm{S} / \mathrm{N}$ & $\begin{array}{l}\text { Samples } \\
\text { Name }\end{array}$ & $\begin{array}{c}\dot{D} \\
\left(\mathrm{nGy} \mathrm{h}^{-1}\right)\end{array}$ & $\begin{array}{l}\text { AED } \\
\left(\mu S v y^{-1}\right)\end{array}$ & $\begin{array}{l}\text { AED } \\
\left(m S v y^{-1}\right)\end{array}$ & $\begin{array}{l}\mathbf{R a}_{\mathrm{eq}} \\
\left(\mathrm{Bq} \mathrm{L}^{-1}\right)\end{array}$ & $\begin{array}{l}\text { ELCR } \\
\left(\begin{array}{lll} \\
\left(x 0^{-3}\right)\end{array}\right.\end{array}$ & $\mathbf{H}_{\mathrm{ex}}$ & $\mathbf{H}_{\text {in }}$ \\
\hline \multicolumn{9}{|c|}{ Study Area } \\
\hline 1 & WSO1 & 7.31 & 568.73 & 0.57 & 15.49 & 1.93 & 0.04 & 0.05 \\
\hline \multirow[t]{2}{*}{2} & WSO2 & 11.89 & 974.95 & 0.98 & 25.42 & 2.98 & 0.07 & 0.09 \\
\hline & MEAN & 9.60 & 771.84 & 0.77 & 20.45 & 2.70 & 0.06 & 0.07 \\
\hline 3 & WSO3 & 11.79 & 1046.86 & 1.05 & 26.15 & 3.22 & 0.07 & 0.09 \\
\hline \multirow[t]{2}{*}{4} & WSO4 & 11.79 & 1038.03 & 1.04 & 25.88 & 3.05 & 0.07 & 0.09 \\
\hline & MEAN & 11.79 & 1042.45 & 1.04 & 26.01 & 3.65 & 0.07 & 0.09 \\
\hline 5 & WSO5 & 16.98 & 1441.05 & 1.44 & 37.08 & 4.59 & 0.10 & 0.13 \\
\hline \multirow[t]{2}{*}{6} & WSO6 & 9.43 & 832.93 & 0.83 & 20.65 & 2.38 & 0.06 & 0.07 \\
\hline & MEAN & 13.21 & 1136.99 & 1.14 & 28.86 & 3.98 & 0.08 & 0.10 \\
\hline 7 & WSO7 & 14.83 & 1351.67 & 1.35 & 32.67 & 3.61 & 0.09 & 0.11 \\
\hline \multirow[t]{2}{*}{8} & WSO8 & 9.33 & 846.59 & 0.85 & 20.57 & 2.32 & 0.06 & 0.07 \\
\hline & MEAN & 12.08 & 1099.13 & 1.10 & 26.62 & 3.85 & 0.07 & 0.09 \\
\hline 9 & WSO9 & 17.56 & 1607.68 & 1.61 & 39.25 & 3.79 & 0.11 & 0.14 \\
\hline \multirow[t]{3}{*}{10} & WSO10 & 13.83 & 1143.85 & 1.14 & 30.01 & 4.72 & 0.08 & 0.11 \\
\hline & MEAN & 15.70 & 1375.76 & 1.38 & 34.63 & 4.82 & 0.09 & 0.12 \\
\hline & $\begin{array}{l}\text { OVERALL } \\
\text { MEAN }\end{array}$ & 12.47 & 1085.23 & 1.09 & 27.31 & 3.80 & 0.07 & 0.09 \\
\hline \multicolumn{9}{|c|}{ Control Area } \\
\hline 11 & WSO11 & 15.33 & 1285.92 & 1.29 & 33.70 & 4.45 & 0.09 & 0.12 \\
\hline \multirow[t]{2}{*}{12} & WSO12 & 11.96 & 1052.58 & 1.05 & 26.27 & 3.12 & 0.07 & 0.09 \\
\hline & MEAN & 13.64 & 1169.25 & 1.17 & 29.98 & 4.09 & 0.08 & 0.11 \\
\hline
\end{tabular}

Radium Equivalent activity Index $(R a \quad$ eq $)$ : The Radium Equivalent Activity Index $\left(\mathrm{Ra}_{\mathrm{eq}}\right)$ in analyzed water samples were calculated using equation (3); presented in Table7. The mean ranged between 20.45 to $34.63 \mathrm{~Bq} \mathrm{~L}^{-1}$ with an average of $27.31 \mathrm{~Bq} \mathrm{~L}^{-1}$ for the study area and between 26.27 to $33.70 \mathrm{~Bq} \mathrm{~L}^{-1}$ with an average of $29.98 \mathrm{~Bq} \mathrm{~L} \mathrm{~L}^{-1}$ for the control area. In the study area, the obtained average value was high in comparison with the control environment but below the world average value of $370 \mathrm{~Bq} \mathrm{~kg}{ }^{-1}$ and hence poses no serious health risk (UNSCEAR, 2000).

Excess Lifetime Cancer Risk (ELCR): The excess life time cancer risk for the analyzed water samples were calculated using equation (4); the results are shown in Table 7. The mean ELCR ranged between $2.70 \times 10^{-3}$ to $4.82 \times 10^{-3}$ with an average of $3.80 \times 10^{-3}$ for the study area while it ranged between $3.68 \times 10^{-3}$ to 4.50 $\mathrm{x} 10^{-3}$ with an average of $4.09 \times 10^{-3}$ for control area. It is important to note that the obtained average values were higher than the world average value of $0.2 \times 10^{-3}$ in both the study and control environments (UNSCEAR, 2000). This implies that staying in this environment with an average of 70 years without interacting with other areas in terms of feeding and shelter may pose serious cancer risk. 
Radiation Hazard Indices: The radiation hazard indices in analyzed water samples, both the external and the internal were calculated using equation (4a) and $(4 \mathrm{~b})$ respectively. The results are shown in Table 7 for radiation hazard indices. The mean external radiation hazard index $\left(\mathrm{H}_{\mathrm{ex}}\right)$ ranged between 0.04 to 0.11 with an average of 0.07 for the study area and 0.07 to 0.09 with an average of 0.08 for the control area, while the mean internal radiation hazard index $\left(\mathrm{H}_{\text {in }}\right)$ ranged from 0.05 to 0.14 with an average of 0.09 for the study area and 0.09 to 0.12 with an average of 0.11 for the control. Both values were found to be lower than the world average value of 1 (unity) and therefore poses no serious health risk (Beretka and Mathew, 1985).

Conclusion: The radionuclides detected in the gamma spectrometry analysis belonged to the naturally-occurring series-decay ${ }^{238} \mathrm{U}$ and ${ }^{232} \mathrm{Th}$ as well as the non-series ${ }^{40} \mathrm{~K} .{ }^{238} \mathrm{U}$ and ${ }^{232} \mathrm{Th}$ concentrations in some food and water samples were found to be higher than the world average value in the study area. The control area showed a trend of low activity concentrations in all the samples analyzed when compared to the study area. This can be attributed to the industrial activities in the study area. The estimation of most of the radiological impact parameters such as the absorbed dose rate, annual effective dose due to ingestion and exposure received outdoor in analyzed soil samples, radium equivalent activity, radiation hazard indices and excess lifetime cancer risk were found to be lower than the world average values. However, the effective dose in some of the samples especially water samples were found to be higher than the world average value. Similarly, the excess lifetime cancer risk values in food and water samples in the study area were found to be higher than the world average value. This poses health hazard that may predispose the populace in the study area to serious health risk.

Acknowledgement: This paper is a part of the research done for environmental monitoring of residents in Fasina village, Ile-Ife, Osun State, Nigeria due to the iron smelting industry located in the area. The authors would like to thank the entire staff of Center for Energy Research and Development (CERD), Obafemi Awolowo University, Ile-Ife, Nigeria for giving their valuable time for the sample preparation and the gamma analysis of the samples.

\section{REFERENCES}

Akinyose, FC; Tchokossa, P; Orosun, MM; Oluyde, SO; Umakha, M; Ochommadu, KK; Olaniyan, A; Ajibade, OA (2018).Radiological Impacts of Natural Radioactivity in Locally Produced
Tobacco Products in Ibadan, Oyo State, Nigeria. Momona Ethiopian Journal of Science (MEJS), V10 (1): 59-7. http://dx.doi.org/10.4314/mejs.v10i1.5

Ali, AA; Hussain, HA; Lubna, AA (2013).Determination of Natural Radiation Contamination for Some Types of Legumes Available in the Iraqi Market. Advance Applied Science Research, 4 (5): 246 - 250.

Amin, RM; Ahmed, F (2013).Estimation of Annual Effective Dose to the Adult Egyptian Population Due to Natural Radioactivity Elements in Ingestion of Spices. Advance Applied Science Research, 4 (5): 350 - 354.

Avwiri, GO; Alao, AA (2013).Natural Radioactivity and Associated Radiation Hazards in Some Consumed Tubers and Cereals in Oil Mining Lease (OML) 58 and 61, Oil and Gas Producing Area, Niger Delta Region of Nigeria. International Journal of Science and Research, 2 (1): $468-473$.

Beretka, J; Mathew, PJ (1985).Natural radioactivity of Australian Buildings, Materials, Industrial Wastes and By-Products. Health Physics, 48, 8795.

Environmental Protection Agency (EPA) (2015).Radioactive Source Reduction \& Management. Poster: Radioactive Scrap - Be Aware! (NUREG/BR-0108, Revision 1).http://www.epa.gov/radiation/understand/path ways.html.

Fitzgerald, JJ (1969).Applied Radiation and Control. Volume 1, Gondon and Breach Science Publication.

Food Balance Sheet (2014). Open Data for Nigeria. African Development Bank Group.

Hall, EJR (2000). Radiobiology for the Radiologist. Printed by Lippincott Williams \& Wilkins 530 W7alnut Street Philadelphia, PA 19106 USA.

International Atomic Energy Agency, (IAEA) (2000). Radiation Protection in Diagnostic and Interventional Radiology.IAEA Training Material on Radiation Protection in Diagnostic and Interventional Radiology, Biological effects of ionizing radiation. Vienna.

International Commission on Radiological Protection, (ICRP) (1994).Dose Coefficient for 
Intakes of Radionuclides by Worker. Publication No: 68 Pergamon Press, Oxford. 1994.

Oluyide SO; Tchokossa P; Akinyose FC; Orosun MM (2018). Assessment of radioactivity levels and transfer factor of natural radionuclides around iron and steel smelting company located in Fashina village, Ile-ife, Osun state, Nigeria. Facta Universities, Series: Working and Living Environmental Protection. 15(3):241-256 DOI: https://doi.org/10.22190/FUWLEP1803241O

Orosun, MM; Alabi, AB; Olawepo. AO; Lawal, TO; Ige, SO (2018).Radiological Safety of Water from Hadejia River. IOP Conf. Ser.: Earth Environ. Sci. 173 (1): 012036. DOI: https://doi.org/10.1088/17551315/173/1/012036.

Orosun, MM; Lawal, TO; Akinyose, FC (2016). Natural radionuclide concentrations and radiological impact assessment of soil and water in Tanke-Ilorin, Nigeria. Zimbabwe Journal of Science \& Technology, 11, 158-172.

Petrucci, RH; Harwood, WS; Herring, FG (2002).General Chemistry. Prentice-Hall $8^{\text {th }}$ ed., pp 1025-26.

Tchokossa, P; Olomo, JB; Balogun FA; Adesanmi CA (2013). Assessment of Radioactivity Contents of Food in the Oil and Gas Producing Areas in Delta State, Nigeria.International Journal of Science and Technology (IJST).Volume 3 No.4, pp 245-250.ISSN 22243577.http://www.ejournalofsciences.org.
Tufail, M; Nasim, A; Sabiba, J; Tehsin, H (2007). Natural Radioactivity Hazards of Building Blocks Fabricated from Soil Two Districts of Pakistan. Journal of Radiological Protection Vol. 27, pp. 481-492.

United Nations Economic Commission for Europe, (UNECE) (2006).Monitoring and response procedures for Radioactive Scrap Metal. New York and Geneva, United Nations. http://www.unece.org/trans/radiation/2ndMeetin g.html.

United Nations Scientific Committee on the Effect of Atomic Radiation, (UNSCEAR) (2000): "Sources and Effects of Ionizing Radiation in Report to the General Assembly with Scientific Annexes" New York, United Nations.

Veiga, RG; Sanches, N; Anjos, RM; Macario, $\mathrm{K}$;Bastos, J; Iguatemy, M; Aguitar, JG; Santos, MA; Mosquera, B; Carvaiho, C;Baptista, M; Umisedo, NK (2006). Measurement of Natural Radioactivity in Brazilian Beach Sands. Radiation Measurements 41: 189-196.

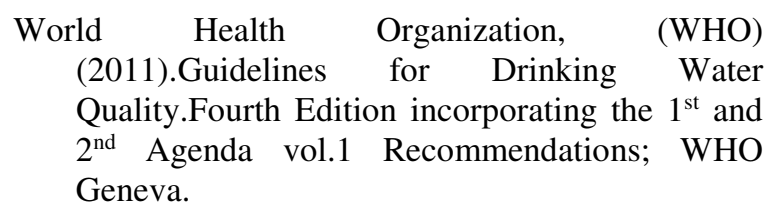

